\title{
Computational and the real energy performance of a single-family residential building in Poland - an attempt to compare: a case study
}

\author{
Piotr Kowalski ${ }^{1, *}$, and Pawel Szałański ${ }^{1}$ \\ ${ }^{1}$ Department of Air Conditioning, Heating, Gas Engineering and Air Protection, Faculty of \\ Environmental Engineering, Wrocław University of Science and Technology, 4/6 C.K. Norwida \\ st. 50-373 Wrocław, Poland
}

\begin{abstract}
The paper presents energy use for heating and ventilation (one of the energy performance components) determined in three ways. A case of a single family building located near Wroclaw in Poland is analyzed. The first and the second variant are both computational and the third presents actual measured energy consumption. Computational variants are based on the Polish methodology for the EPC (the Energy Performance Certificate). This methodology is based on 'the Energy Performance of Buildings Directive 2010/31/EU'. Energy use for heating and ventilation is calculated using monthly method presented in EN ISO 13790. In the first computational option standard input data (parameters such as indoor and outdoor air temperature etc. are taken from standards and regulations) are implemented. In the second variant this input data are partially taken from measurements. The results of energy use from both computational variants are compared to the actual measured energy consumption. On the basis of this comparison the influence of three factors: solar radiation heat gains, building air tightness and the SCOP of the heat pump on energy use calculations are analyzed. Conclusions aim to point the differences between them and the actual energy consumption.
\end{abstract}

\section{Introduction}

In the common understanding of the buildings users the Energy Performance Certificate (the EPC), prepared in connection with the requirements of Directive [1], should allow to estimate the real energy consumption and the rough cost of heating. However, this idea is rather misleading and can cause some doubts. Thus, the question arises whether the calculation methods indicated by the Polish regulations on energy

\footnotetext{
${ }^{*}$ Corresponding author: piotr.kowalski@pwr.edu.pl
} 
performance certificates [2] (mostly in line with European standards) can give a result close to the real energy consumption for the analyzed building.

It is obvious that regardless of calculation models, the implementation of the standard values (not real) of input data does not allow to obtain the result close to the real energy consumption. However, in the analyzed building a user has installed a self-designed measuring and logging system in order to observe the energy and water consumption and to manually control indoor air temperatures in the building. Therefore, the article attempts to answer the question: whether on the basis of measurements from this system supplemented by additional instantaneous measurements carried out by authors one can predict real energy consumption.

\subsection{Description of the analyzed building}

The subject of the study (Fig. 1 and 2) is located in Poland near Wroclaw. This is a two storey single-family house with a garage, an attic and without basement. Building was built in the traditional brick technology with two-layer walls of hollow bricks called Porotherm and insulated with an expanded polystyrene. The roof is insulated with a mineral wool. Heat transfer coefficients calculated due to $[3,4]$ are as follows: external walls $U_{\text {wall }}=0,22 \mathrm{~W} /\left(\mathrm{m}^{2} \mathrm{~K}\right)$, the floor on the ground $U_{\text {equiv }}=0,18 \mathrm{~W} /\left(\mathrm{m}^{2} \mathrm{~K}\right)$, the ceiling of the attic $U_{\text {ceilling }}=0,15 \mathrm{~W} /\left(\mathrm{m}^{2} \mathrm{~K}\right)$, the roof $\mathrm{U}_{\text {roof }}=0,20 \mathrm{~W} /\left(\mathrm{m}^{2} \mathrm{~K}\right)$, windows $\mathrm{U}_{\text {win }}=1,40 \mathrm{~W} /\left(\mathrm{m}^{2} \mathrm{~K}\right)$ - value assumed. The usable area (calculated using standardized methods) of the building is $228,3 \mathrm{~m}^{2}$, plus garage area of $39,9 \mathrm{~m}^{2}$, while the floor area with controlled temperature of the indoor air equals $A_{f}=308,7 \mathrm{~m}^{2}$.

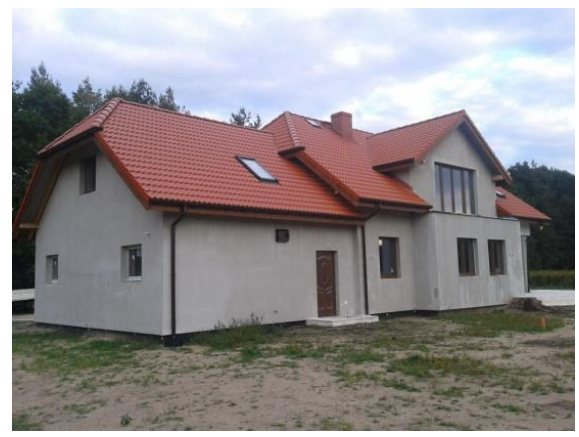

Fig. 1. The case study: a view of the single-family house.
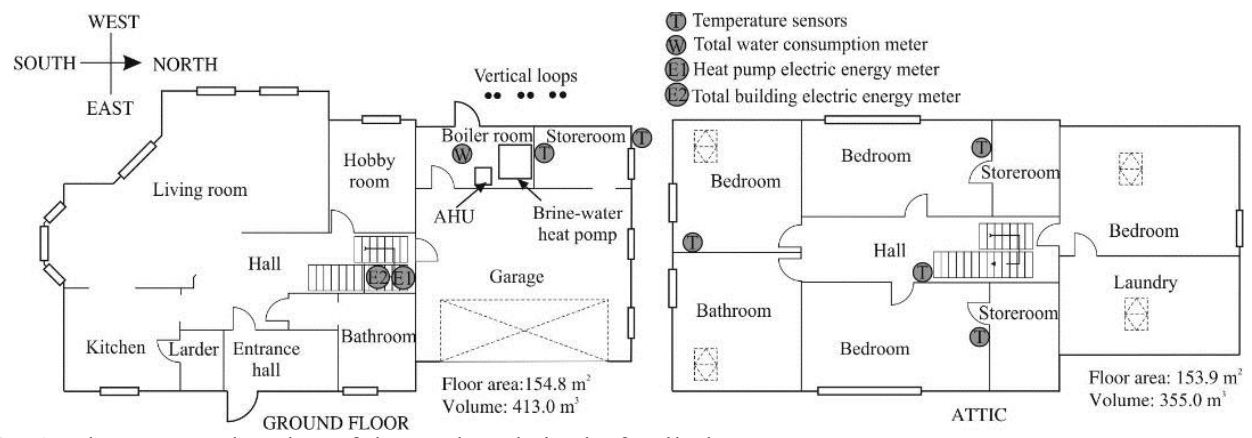

Fig. 2. The case study: plan of the analyzed single-family house.

The building external volume (calculated according to the external dimensions) equals $1175 \mathrm{~m}^{3}$, ventilated-internal building volume is $768 \mathrm{~m}^{3}$ and the ratio of external barriers area and external volume of the building $\mathrm{A} / \mathrm{V}=0,4101 / \mathrm{m}$. In 2013 the building 
was inhabited by two adults and one child and in 2015 by two adults and two children. The building structure was assumed as a semi-heavy. The facility is equipped with the installation of heating, ventilation, cooling and hot water supply (Fig. 3). The heat source is a water/brine heat pump (heating capacity $12 \mathrm{~kW}$ due to EN 14511). Ventilation in the building provides an air handling unit with heat recovery heat exchanger.

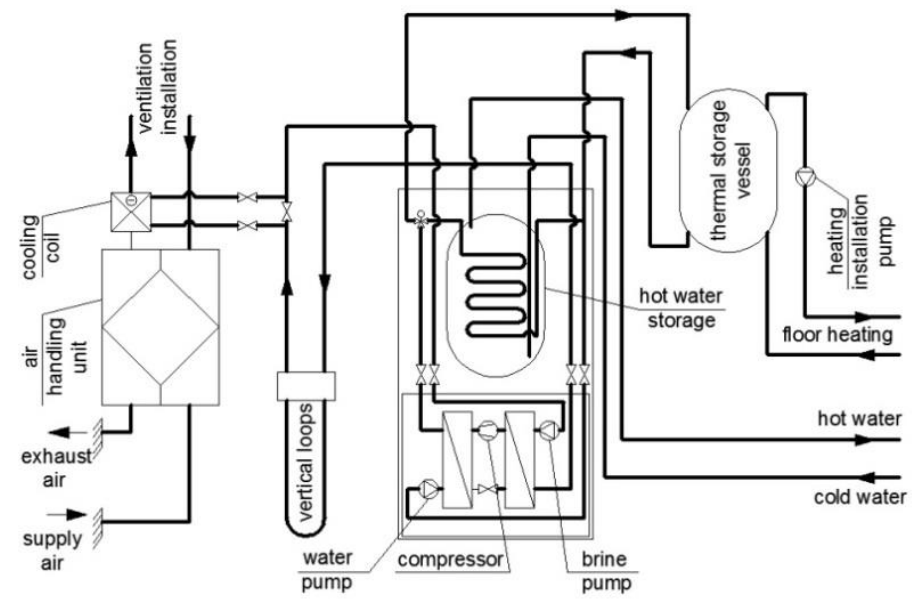

Fig. 3. The case study: A scheme of installations in analyzed building.

\subsection{The measurements description}

A measuring self-designed system (by P. Piotrowski) was installed in the building by the owner P. Piotrowski. Measurements were logged in 10 minute intervals. Measuring system consists of (Fig. 2):

- digital air temperature sensors type DS18B20 Maxim Integrated (accuracy $\pm 0,5^{\circ} \mathrm{C}$ ), where:

○ indoor air temperature sensors were located on the internal walls $30-40 \mathrm{~cm}$ above floor,

- outdoor air temperature sensor was located on the northern wall $1,7 \mathrm{~m}$ above the ground,

- electric energy meter (accuracy class B) for the heat pump and heating installation pump,

- electric energy meter (accuracy class 1) for the whole house,

- typical water meter with pulse transmitter.

Additionally, authors carried out the below described measurements.

The mechanical ventilation supply and exhaust flows were measured once in two operating modes: low flow Monday - Sunday 24:00-6:00, Monday - Friday 9:00-14:00; normal flow Monday - Friday 6:00-9:00 and 14:00-24:00; Saturday - Sunday 6:00-24:00. Measured flows are assumed to be constant during analyzed period respectively for operating modes. The total flows were calculated as sum of flows measured on terminal elements of the ventilation installation. Flows on the terminal elements were measured using vane-type anemometer type Airflow LCA301 (accuracy $\pm 1 \%$ of reading $+0.02 \mathrm{~m} / \mathrm{s}$ ). A heat recovery efficiency in air handling unit (AHU) was determined by measuring temperatures of supply, exhaust and outdoor air while outdoor air temperatures were close to the average air temperature of the heating season.

Temperatures were measured using an electronic instrument type TESTO 435-2 with air temperature probe (accuracy $\pm 0,2^{\circ} \mathrm{C}$ ). 
Electric power of heating installation pump was measured using wattmeter BRYMEN BM357s. This pump operates all the heating period.

\section{Assumption to the calculations}

The following calculations of energy demand and energy consumption apply to the part of the energy performance: for heating and ventilation purposes (without heating installation pump and fans in AHU). The comparison of the analyzed variants does not apply to the energy demand for hot water. In those calculations two computational variants were considered: with a standard input data (from standards and regulations) variant I and with a selected real input data (mainly obtained from user self-designed measuring system and instantaneous measurements carried out by authors) - variant II. Moreover, in the variant III the real energy consumption for heating and ventilation was determined on the basis of the measurements.

\subsection{Description of the computational model}

Computational energy performance (variant I and II) was determined due to monthly method presented in Polish translation of EN ISO 13790 [5] with additional assumptions presented in Polish regulations [2]: calculations do not take into account heat flux of thermal radiation to the sky from building elements.

In particular, the calculation was carried out according to the models from the following standards:

- Heat transfer coefficients $\left(\mathrm{U}, \mathrm{W} /\left(\mathrm{m}^{2} \mathrm{~K}\right)\right)$ on the basis of Polish translation of EN ISO 6946 [3].

- Linear heat transfer coefficients of thermal bridges $(\Psi, \mathrm{W} /(\mathrm{m} \mathrm{K})$ assumed after Polish translation of EN 14683 [6].

- Heat loss via the ground with floor heating are based on Polish translation of EN ISO 13370 [4].

- Transmission and ventilation heat loss coefficient $\left(\mathrm{H}_{\mathrm{T}}, \mathrm{H}_{\mathrm{V}}, \mathrm{W} / \mathrm{K}\right)$ on the basis of Polish translation of EN ISO 13789 [7].

\subsection{Description of the input data}

The final energy demand of the building depends on the number of input data, such as: outdoor and indoor air temperatures, solar and internal heat gains, air tightness of the building, exposure to the wind, the efficiency of the heating and ventilation systems and walls, roof, floor, windows, door heat transfer coefficients. The way of specifying them in particular variants is described below.

In variant I calculations were carried out with standard input data assumed on the basis of Polish regulations [2].

In variant II the following input data were obtained from the measurements or assumed on the basis of the measurements:

- measured outdoor air temperature was separately averaged for each month,

- indoor air temperature was averaged (for each month) from available sensors (Fig. 2) respectively for living space and utility area (garage, boiler room, store room on the ground floor),

- to estimate the internal heat gains:

○ total measured electric energy consumption for the heat pump,

- electric energy consumption for exhaust fan in AHU, 
- electric energy consumption for heating installation pump, were subtracted from the total measured electric energy consumption of the building and the result was added to heat gains from residents,

- supply, exhaust flows and heat recovery efficiency of the ventilation installation.

Other input data in variant II were assumed on the basis of Polish regulations [2]. Seasonal control system efficiency was an exception, which was assumed as 1.0. It was due to basing on measured values of indoor temperatures in this variant. Temperatures were measured and logged every 10 minutes, and then averaged for every month. Therefore, it was assumed that the effect of temperature fluctuations [8] due to the control system efficiency was already taken into account in calculations. Variant I assumed seasonal control system efficiency differently - equal to 0.76 for the analyzed floor heating system with central and without local regulation [2]. It was due to the calculations based on the constant indoor temperature.

The results of the calculations in variant II were presented for two years: 2013 and 2015 except from June to September.

Variant III presents measured energy consumption for the same periods with the following assumptions:

- The final energy use for hot water was subtracted from the total measured heat pump energy consumption during the heating period to estimate the final energy consumption for heating and ventilation. In consequence, the final energy used by heating installation was estimated.

- The final energy consumption for hot water supply was determined on the basis of the heat pump energy consumption measurements in the summer months. The periods when energy was used by the heat pump only for hot water supply were taken into account. Average estimated value of final energy for hot water supply equals 51.7 $\mathrm{kWh} /$ month for the year 2013 and $74.4 \mathrm{kWh} /$ month for the year 2015.

In all the variants energy consumption in June and September was omitted in order to avoid an error related to specifying the beginning and the end of the heating season.

Comparison of input data for all three variants are presented in the Table 1.

Table 1. Comparison of the assumptions for variants I, II and measurements for III.

\begin{tabular}{|c|c|c|c|c|c|c|c|c|c|}
\hline \multirow{2}{*}{ Input data } & Month & \multirow[t]{2}{*}{ I } & \multirow[t]{2}{*}{ II } & \multirow[t]{2}{*}{ III } & \multirow[t]{2}{*}{ IV } & \multirow[t]{2}{*}{ V } & \multirow[t]{2}{*}{$\mathrm{X}$} & \multirow[t]{2}{*}{ XI } & \multirow[t]{2}{*}{ XII } \\
\hline & Variant & & & & & & & & \\
\hline \multirow{3}{*}{ Outdoor air temperature, ${ }^{\circ} \mathrm{C}$} & I [9] & -0.4 & -0.7 & 2.8 & 7.3 & 12.7 & 8.9 & 3.8 & -1.1 \\
\hline & $\begin{array}{l}\text { II, III } \\
\text { (2013) }\end{array}$ & 0.3 & 0.0 & -1.1 & 8.8 & 14.3 & 9.9 & 5.0 & 1.8 \\
\hline & $\begin{array}{l}\text { II, III } \\
(2015)\end{array}$ & 2.0 & 1.2 & 5.1 & 8.8 & 13.6 & 7.8 & 5.5 & 4.8 \\
\hline \multirow{3}{*}{$\begin{array}{l}\text { Indoor air temperatures, }{ }^{\circ} \mathrm{C} \text { : } \\
\text { - living space } \\
\text { - utility area (garage, boiler } \\
\text { room, store room on the } \\
\text { ground floor) }\end{array}$} & I & \multicolumn{8}{|c|}{$\begin{array}{c}20.4[10] \\
8.1[10]\end{array}$} \\
\hline & $\begin{array}{l}\text { II, III } \\
(2013)\end{array}$ & $\begin{array}{l}20.5 \\
10.3\end{array}$ & $\begin{array}{l}21.3 \\
11.4\end{array}$ & $\begin{array}{l}20.8 \\
11.0\end{array}$ & $\begin{array}{l}21.3 \\
15.3\end{array}$ & $\begin{array}{l}21.8 \\
18.8\end{array}$ & $\begin{array}{l}20.9 \\
17.4\end{array}$ & $\begin{array}{l}20.3 \\
14.9\end{array}$ & $\begin{array}{l}20.4 \\
12.6\end{array}$ \\
\hline & $\begin{array}{l}\text { II, III } \\
(2015)\end{array}$ & $\begin{array}{l}21.7 \\
12.9\end{array}$ & $\begin{array}{l}22.0 \\
12.4\end{array}$ & $\begin{array}{l}22.7 \\
15.4\end{array}$ & $\begin{array}{l}22.2 \\
17.0\end{array}$ & $\begin{array}{l}23.2 \\
20.6\end{array}$ & $\begin{array}{l}23.7 \\
17.9\end{array}$ & $\begin{array}{l}22.6 \\
16.1\end{array}$ & $\begin{array}{l}22.8 \\
15.1\end{array}$ \\
\hline
\end{tabular}




\begin{tabular}{|c|c|c|}
\hline $\begin{array}{l}\text { Average supply, exhaust } \\
\text { air flow and the (living } \\
\text { space / utility area) } \mathrm{m}^{3} / \mathrm{h}\end{array}$ & $\begin{array}{c}\text { I } \\
\text { II, III }\end{array}$ & $\begin{array}{l}146 \text { and } 146 / 0 \text { and } 20 \\
140 \text { and } 140 / 0 \text { and } 20\end{array}$ \\
\hline $\begin{array}{l}\text { Heat recovery efficiency in } \\
\text { ventilation system, } \%\end{array}$ & I, II & 60 \\
\hline $\begin{array}{l}\text { Result of building air } \\
\text { tightness test } n_{50}, h^{-1}\end{array}$ & I, II & $4.0[2]$ \\
\hline Solar radiation heat gains & I,II & Calculated on the basis of climate data [9] \\
\hline $\begin{array}{l}\text { Internal heat gains (living } \\
\text { space / utility area), } \mathrm{W} / \mathrm{m}^{2}\end{array}$ & $\begin{array}{c}\text { I } \\
\text { II }(2013) \\
\text { II (2015) }\end{array}$ & $\begin{array}{l}6.8 / 6.8[2] \\
1.16 / 2.51 \\
1.41 / 2.51\end{array}$ \\
\hline $\begin{array}{l}\text { SCOP (EN } 14825[12]- \\
\left.\text { average climate, } 35^{\circ} \mathrm{C}\right)\end{array}$ & I, II & $4.7[11]$ \\
\hline \multirow{2}{*}{$\begin{array}{l}\text { Seasonal control/heat } \\
\text { storage/distribution } \\
\text { efficiencies system }\end{array}$} & I & $0.76 / 0.95 / 1.0[2]$ \\
\hline & II & $1.0 / 0.95 / 1.0[2]$ \\
\hline
\end{tabular}

\section{Results}

The results of the calculations in all the variants are presented in the Table 2 . The final energy for heating and ventilation in variant I is much lower than in variant II. It is caused by different input data. Moreover, variant II gives much lower values than variant III. The difference can be due to the following reasons: the imperfection of the computational model and the discrepancies between the assumptive and the actual input data. It was estimated that the real air tightness test result, the real solar radiation gains and the real SCOP of the heat pump were the most unsure among the assumptive input data in view of the lack of information on their values.

Table 2. Final energy consumption for heating and ventilation.

\begin{tabular}{|c|c|c|c|c|}
\hline Variant I & Variant IIe 2013 & Variant III 2013 & Variant IIe 2015 & Variant III 2015 \\
\hline $2723 \mathrm{kWh}$ & $3146 \mathrm{kWh}$ & $4547 \mathrm{kWh}$ & $3241 \mathrm{kWh}$ & $4648 \mathrm{kWh}$ \\
\hline
\end{tabular}

The system created by the user does not give the possibility of determining this input data. Due to the inability to identify those values their impact on the result was analyzed. In the consequence six sub-options for variant II were defined in Table 3.

For all of the sub-options the SCOP of the heat pump was fitted so as to obtain the result of the energy demand equal to real energy consumption. In consequence the influence of solar radiation heat gains, building air tightness and efficiency of the heating system on energy use for heating and ventilation was presented (Figure 4). 
Table 3. Sub-options for variant II.

\begin{tabular}{|c|c|c|c|c|c|c|}
\hline \multirow{2}{*}{ Parameter } & A & B & C & D & E & F \\
\cline { 2 - 7 } & $50 \%$ of & $100 \%$ of & $150 \%$ of & $50 \%$ of & $100 \%$ of & $150 \%$ of \\
\cline { 2 - 7 } $\begin{array}{c}\text { Solar } \\
\text { radiation } \\
\text { heat gains }\end{array}$ & \multicolumn{4}{|c|}{ value calculated on the basis of climate data [9] } \\
\hline $\begin{array}{c}\text { Result of } \\
\text { building air } \\
\text { tightness } \\
\text { test } \mathrm{n}_{50}\end{array}$ & $\begin{array}{c}\text { Maximum for building with } \\
1.5 \mathrm{~h}^{-1}\end{array}$ & $\begin{array}{c}\text { Due to Polish regulations [2], value } \\
\text { mechanical ventilation due to Polish } \\
\text { regulations [10] }\end{array}$ & $\begin{array}{c}4.0 \mathrm{~h}^{-1} \\
\text { which should be assumed in calculations } \\
\text { when test was not made }\end{array}$ \\
\hline
\end{tabular}

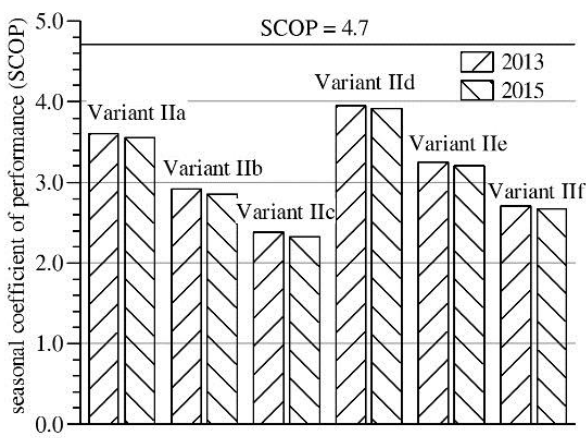

Fig. 4. Theoretical SCOP corresponding to the real final energy consumption for sub-options of variant II.

\section{Conclusions}

The presented analysis (especially comparison of variant I and III) shows that using monthly method (due to the Polish methodology for EPC) failed to predict the actual energy consumption. So it indicates that the EPC methodology is rather to assess the energy performance of the design of the building and not to predict the actual energy consumption. After changing a part of the standard input data on the real values (variant II) the result is closer to the real energy consumption (variant III). However, the difference still remains significant. It can be mainly caused by the imperfection of the model and the discrepancy between real values of the input data and values implemented in calculations:

- SCOP was assumed according to the EN 14825 standard and not measured,

- U-values were calculated or assumed and not measured,

- hot water energy consumption was assumed equal in winter-time and in summer-time,

- occupation patterns (internal gains) were declared by building user and not registered,

- solar gains were based on standard climatic data and not measured,

- the mechanical ventilation rate and heat recovery efficiency were measured once in each of the operating modes and not registered during all period.

The difference between the real SCOP of the heat pump and the standard SCOP (due to EN 14825) could be mainly caused by:

- the standard SCOP is determined for standard conditions and not for real,

- poor adjustment of the heat pump to the needs of the building,

- continuous operation of the buffer charging pump in the heating season. 
Even if the input data (Variant IIa-IIf) is significantly changed the result does not coincide with the real energy use of the building (Figure 4). In order to reduce resulting uncertainty more real input data should be implemented to the calculations and the following actions should be undertaken in the future:

- expansion of the measuring and logging system with: a heat meter for the heat pump (to determine the real SCOP of the heat pump), solarimeter (to better estimation of solar gains), flow-meters and temperature sensors of ventilating air (for better estimation of ventilating flows and heat recovery efficiency),

- performance of an air tightness test of the building envelope and measurements of a real U-value.

Presented research and analysis are part of the research task financed from special-purpose subsidies of Ministry of Science and High Education of Poland earmarked for the development of young scientists and doctoral students.

The authors would like to thank Piotr Piotrowski for providing results of measurements.

\section{References}

1. Directive 2010/31/EU of the European Parliament and of the Council of 19 May 2010 on the energy performance of buildings (recast), Official Journal of the European Union, http://eur-lex.europa.eu/eli/dir/2010/31/oj

2. Regulation of Minister of Infrastructure and Economic Development (21 February, 2015) on the methodology for determining the energy performance of building or part of the building and energy performance certificates. (in Polish)

3. PN-EN ISO 6946 Building components and building elements - Thermal resistance and thermal transmittance - Calculation methods (in Polish)

4. PN-EN ISO 13370:2007 Thermal performance of buildings - Heat transfer via the ground - Calculation methods (in Polish)

5. PN-EN ISO 13790:2008 Energy performance of buildings - Calculation of energy use for space heating and cooling (in Polish)

6. PN-EN ISO 14683:2007 Thermal bridges in building construction - Linear thermal transmittance - Simplified methods and default values (in Polish)

7. PN-EN ISO 13789:2007 Thermal performance of buildings - Transmission and ventilation heat transfer coefficients - Calculation method (in Polish)

8. G. Dall'O', Green Energy Audit of Buildings, A Guide for Sustainable Energy Audit of Buildings, Springer-Verlag, London (2013)

9. Ministry of Infrastructure and Building, Typical statistical climate data for the Polish area for building energy performance purposes. (in Polish), Web Page: http://mib.gov.pl/2-Wskazniki_emisji_wartosci_opalowe_paliwa.htm), [accessed: 26 January, 2017]

10. Regulation of Minister of Infrastructure and Economic Development (12 April, 2002) on the technical conditions, which are to be met by buildings and their location (in Polish)

11. NIBE AB Sweden, Installer manual NIBE F1245 Ground source heat pump, IHB PL 1602-1 331498 (in Polish)

12. EN 14825 Air conditioners, liquid chilling packages and heat pumps, with electrically driven compressors, for space heating and cooling - Testing and rating at part load conditions and calculation of seasonal performance 